\title{
The influence of a colony's queen state on the drifting of drone honey bees (Apis mellifera $L$ )
}

\author{
RW Currie *, SC Jay \\ University of Manitoba, Department of Entomology, Winnipeg, Manitoba, Canada, R3T 2N2
}

(Received 24 July 1990; accepted 25 February 1991)

\begin{abstract}
Summary - Drones were marked individually with numbered tags and introduced into pairs of hives that were spaced $1 \mathrm{~m}$ apart facing south. The queen state of one colony in each pair was altered (ie with a caged-virgin queen, caged-mated queen, mated-laying queen, queenless or pheromone trans-9-oxodecenoic acid) and the other member of the pair remained queenright. Drifting of 4 independent age groups of drones (5-10, 10-15, 15-20 and 20-25-d old) was studied. A higher proportion of drones drifted to colonies with caged-virgin queens or to colonies with lures containing a component of the virgin queen's pheromone, trans-9-oxodec-2-enoic acid, than to either queenless colonies, queenright colonies or colonies with caged-mated queens. The proportion of drones that drifted to colonies containing virgin queens increased with the age of the drone. There was a tendency for drones from queenright colonies to drift westward. This appears to have masked the attraction of drones to pairs of hives that had the pheromone or virgin queen-treated colonies in the westerly position. Drift of drones away from colonies with virgin queens was not significantly lower than drift from either queenright or queenless colonies.
\end{abstract}

honeybee queen / pheromone / drone / drifting / mating flight

\section{INTRODUCTION}

Little is known about how a colony's queen state can influence the behaviour of its own drones, or the drones from neighbouring colonies. Formerly, colonies that had virgin queens were not thought to attract drones from other colonies or to retain their own drones (Butler, 1939; Levenets, 1951). Although Currie (1982) observed large members of drones drifting to colonies with virgin queens, he speculated that this might be due to the absence of a queen.

More drones from queenright colonies drift into queenless colonies than into queenright colonies (Free and SpencerBooth, 1961). However, differences in drone drift between queenright and queenless colonies do not always occur and may depend upon the number of drifting drones or the direction that hives face (Currie and Jay, 1989). Drone drift between pairs of colonies that are queenless or have virgin queens is the same if both colonies have the same queen state, regardless of the direction that hives face (Currie and Jay, 1989). Differences in the level of drone drift between colonies with different queen states may be due, in part, to differences between the number of drones repelled by queenless and queen-

\footnotetext{
* Correspondence and reprints
} 
right colonies (Free and Spencer-Booth, 1961; Currie and Jay, 1989). High levels of drift to colonies with virgin queens, however, could also result from attraction of drones by virgin queen pheromones (Currie, 1982).

Virgin queens produce a pheromone that attracts drones during a mating flight (Gary, 1962). The major component of the pheromone that is attractive to drones is trans-9-oxodec-2-enoic acid (9-ODA) which is produced by the queen's mandibular glands (Butler and Fairey, 1964; Blum et al, 1971; Boch et al, 1975). The attractiveness of a queen is correlated to the quantity of 9-ODA in the queen's mandibular glands (Boch et al, 1975). Newly emerged virgin queens have very little of this pheromone, but develop about the same quantity as that found in mated queens by the time they are 5-10 d old (Butler, 1961; Butler and Fairey, 1964). Drones are not attracted by pheromone from virgin queens when both are in the hive (Pain, 1973) and are not known to mate with virgin queens inside the hive.

The objectives of this study were to determine if drone drifting is influenced by the age and condition of a queen, queen pheromones or the age of drones.

\section{MATERIALS AND METHODS}

Drones were reared from 7 colonies, each of which contained a Caucasian queen. Newly emerged drones were selected, marked with uniquely numbered and coloured tags, and randomly assigned to each treatment (Currie and Jay, 1989). Fifty drones were introduced into each colony on the same day that they were marked, after drone flight activity had ended for the day (ie $\approx 20: 00 \mathrm{~h}$ ) (Currie and Jay, 1988).

Twenty-four single chamber Langstroth hives were placed in 12 pairs. At the beginning of each experiment, colony populations were equalized so that each colony contained 6 frames of worker bees, 3 frames of brood and equal amounts of stored honey and pollen. Four independent age groups of drones were tested in pairs of hives that had 6 different "queen states". Hives of each pair were spaced $1 \mathrm{~m}$ apart and pairs of hives were separated by a minimum distance of $200 \mathrm{~m}$. The hives were positioned so that the hive entrances faced south (fig 1). In 6 of the pairs, the queen states were altered in colonies on the west side of each pair (block 1) and in the other 6 pairs the queen states were altered in the colonies on the east side of each of the pair (block 2) (fig 1). All other hives had mated-laying queens. The 6 different "queen states" tested were: mated-laying queens, queenless, caged-mated queens, 1-7d-old virgin queens, $>7$-d-old virgin queens and queenless colonies with trans-9-oxodec-2-enoic acid (a component of a queen's pheromones).

Fifty newly-emerged, individually marked drones were introduced into each hive at 5-d intervals on each of 4 different dates. Five $d$ after the last age group of drones were introduced all of the colonies were inspected for the next 5 consecutive $d$ on which drones flew to determine the number of drones drifting on each day. Thus 4 independent age groups, of 5-10-d-old, 10-15-d-old, 15-20-d-old and 20-25-d-old drones were present in each colony and the proportion of drones that drifted was determined on 4 consecutive days. Colonies were carefully searched each morning before drone flight began, and the numbers and colours of marked

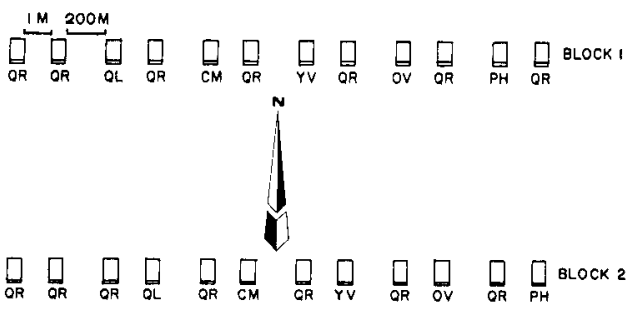

Fig 1. The arrangement of hives to determine the effects of queen state on the proportion of drones that were attracted to and retained by colonies. Each pair was separated by a minimum distance of $200 \mathrm{~m}$. QR = mated laying queen; $\mathrm{QL}=$ queenless; $\mathrm{CM}=$ caged mated queen; $Y V=$ caged young vigin queen $(>7-d$ old); $O V=$ caged old virgin queen ( $>7$-d old); $\mathrm{PH}=$ pheromone $(100 \mu \mathrm{g}$ trans-9-oxodec-2enoic acid). 
drones present in each colony were recorded. The proportion of drones that drifted was calculated by dividing the number of drones that drifted from a hive each day by the total number of drones that were found in that hive on the previous day. The entire experiment was replicated in different colonies on 9 September, 1983, 23 July, 6 August and 13 August, 1984.

Mated-laying queens had unrestricted movement throughout the experimental period. In each of the 5 other treatments the colony's queen was removed before any drones were introduced into the hive. Treatments (ie queen states) were altered in these colonies on the day before colonies were examined for marked drones. Virgin queens were reared using the Doolittle method (Laidlaw and Eckert, 1974) and/or by placing frames of worker eggs into queenless colonies. Mated and virgin queens were put in queen cages that were screened on 2 sides, and placed between the centre frames at the top of each hive, $\approx 5 \mathrm{~cm}$ from the back of the hive.

The pheromone, trans-9-oxodec-2-enoic acid (Galaxo Group Ltd, London) was dissolved in methanol and $100 \mu \mathrm{g} / 25 \mathrm{ml}$ of the pheromone was applied to $5 \times 5 \times 2 \mathrm{~mm}$ square blocks of plastic foam (after Boch et al, 1975). The pheromone blocks were suspended in the hives from a wire, in the same relative position as were caged queens. Blocks with pheromone were replaced daily.

A weighted analysis of variance in the logit scale was used to analyze the data (Snedecor and Cochran, 1980). A value of $1 / 2$ was added to each cell prior to analysis. The positions of the colonies were treated as a blocking factor (fig 1). The experiment was arranged as a factorial ANOVA with repeated measurements over time. Queen state, drone age, block, and date were main factors and counts over time was the sub-plot factor. Separate analyses were performed on the drones drifting to the treated colonies ("attraction") and the drones drifting from the treated colonies ("retention").

\section{RESULTS}

\section{Attraction of drones}

Although there were significant differences in the level of drone drift on different dates, there was no significant interaction between the date on which the experiments took place and effects that were caused by the colony's "queen state". The relative attractiveness of colonies with different queen states did vary, however, with the position of the treated hive (ie the block in fig 1) and with the age group of drones sampled $(P<0.0001)$.

Irrespective of whether queen state was altered in the west or east position, colonies with virgin queens attracted significantly more drifting drones than queenless colonies (block 1, $P<0.007$; block $2, P<$ 0.009 ) (figs 2 and 3 ). Colonies containing the pheromone 9-ODA attracted even more drones than colonies with virgin queens, in both block $1(P<0.05)$ and block $2(P<0.02)$. The level of drift to colonies with caged-mated queens did not differ from mated-laying queens in either of the 2 blocks.

The relative attractiveness of queenright and queenless colonies to drifting drones varied with the position of colonies with altered queen states. In block 2 , where colony queen state was altered in the east postion, there was no significant difference in drift to queenright or queenless colonies (fig 2). However, in block 1, where colony queen state in the west position was altered, drift to queenright colonies was sig- 

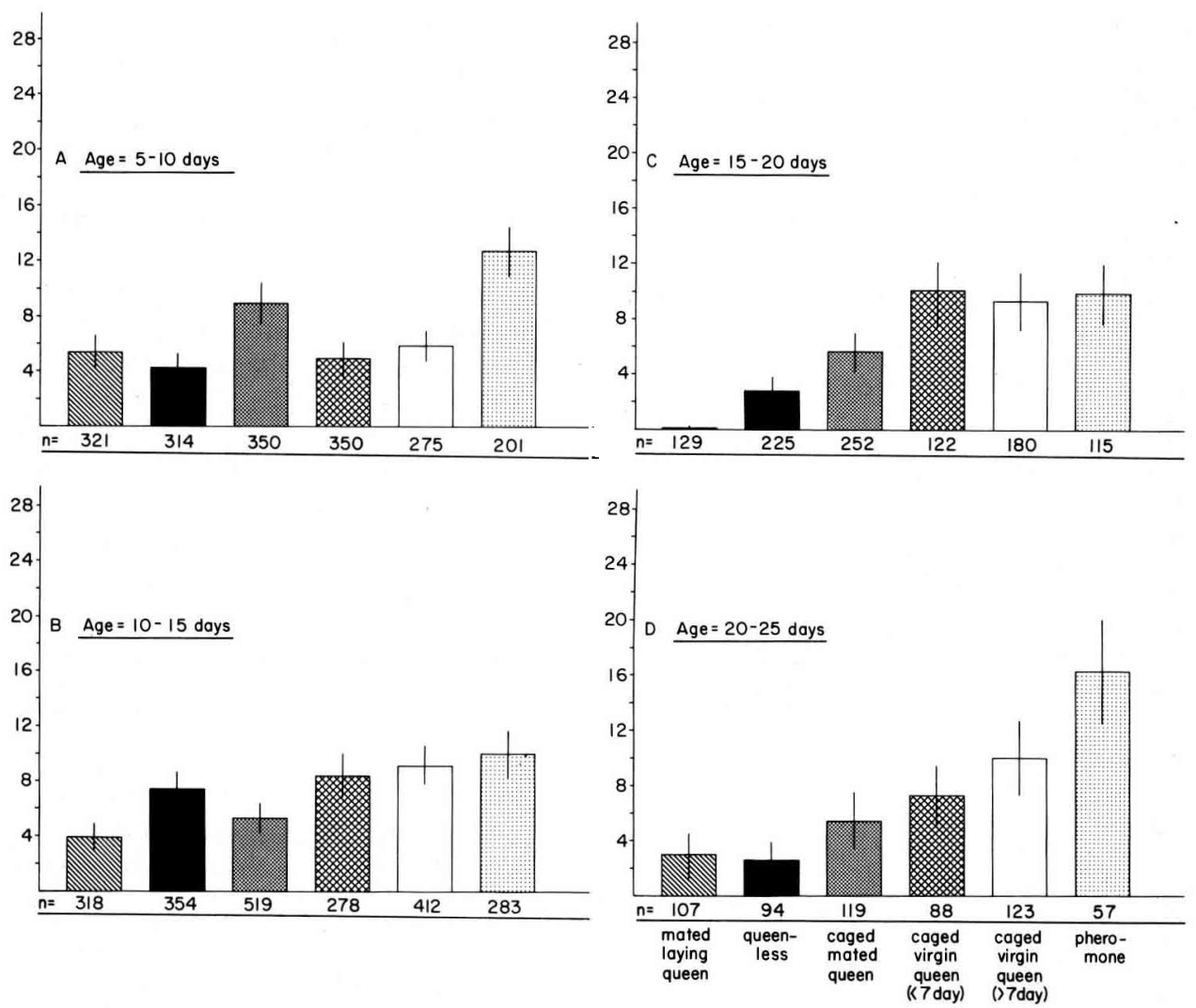

Fig 2. The relative attractiveness of colony queen state to 4 age groups of drones that drifted from queenright colonies to treated colonies $1 \mathrm{~m}$ to the east (block 2). $n=$ total number of drones observed (on which proportions were based).

nificantly greater than drift to queenless colonies $(P<0.002)$ (fig 3 ).

The positioning of colonies also affected the relative attractiveness of colonies with mated and virgin queens. When colonies with altered queen states were in the east position (in block 2), and drift to colonies with mated queens was low, significantly more drones drifted to colonies with virgin queens than to queenright colonies $(P<0.007)$ (fig 2). In block 1 , however, where colonies with altered queen states were in the west position and drift to queenright colonies was much higher, the levels of drift to colonies with virgin queens did not differ from colonies with mated queens (fig 3 ).

The relative attractiveness of a colony's queen state to drifting drones depended upon the age of drone, as indicated by significant interactions between queen state and drone age in both block $1(P<0.0001)$ and block $2(P<0.005)$. Older drones were more attracted to colonies containing 

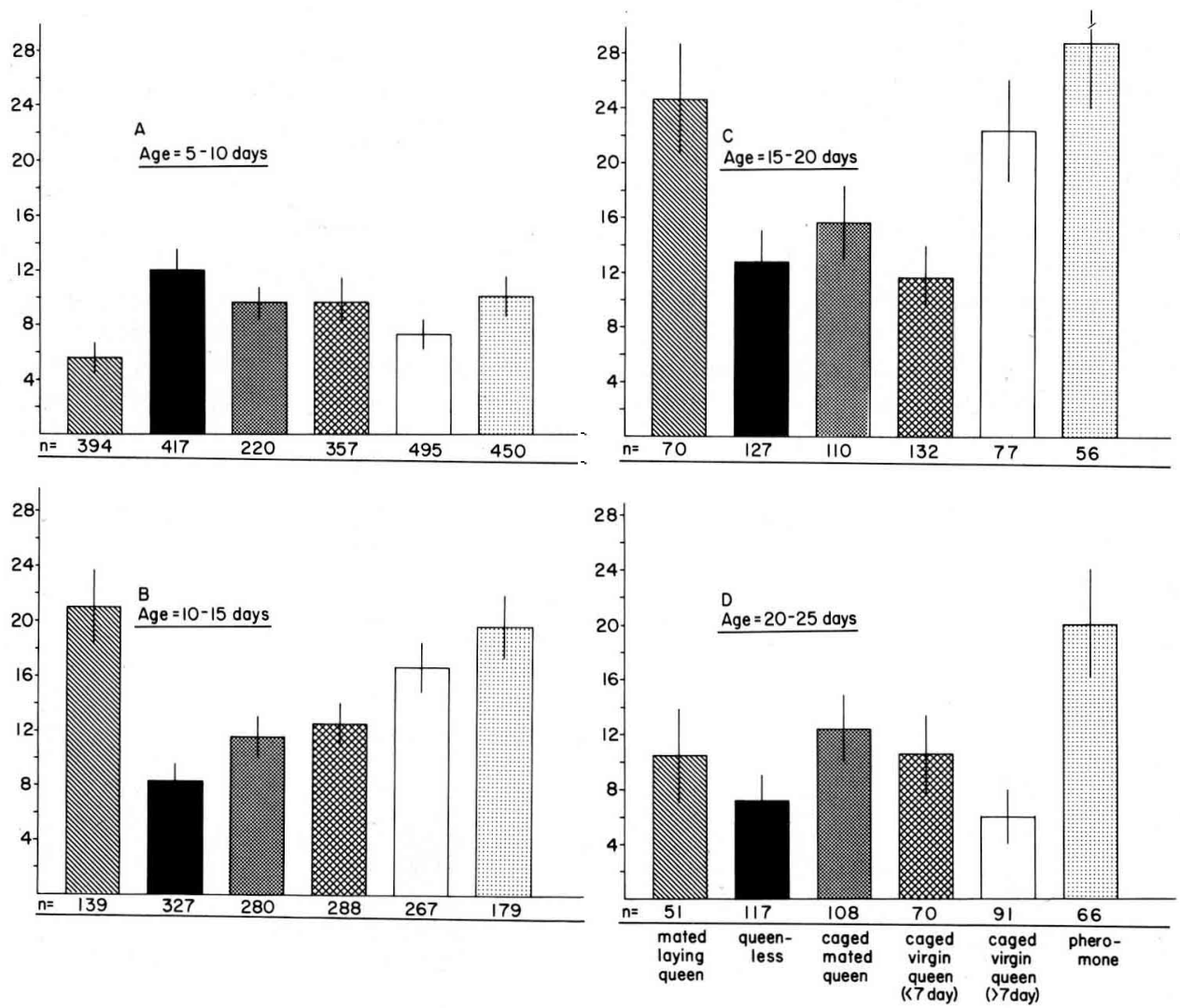

Fig 3. The relative attractiveness of colony queen state to 4 age groups of drones that drifted from queenright colonies to treated colonies $1 \mathrm{~m}$ to the west (block 1 ). $n=$ total number of drones observed (on which proportions were based).

9-ODA or virgin queens than younger drones. Drift towards colonies with pheromone increased relative to colonies with young virgin queens with an increase in the age of drones from $10-15$ to $20-25 \mathrm{~d}$ old in block $2(P<0.002)$ and from $5-10$ to $20-25 \mathrm{~d}$ old in block $1(P<0.0001)$ (figs 2 and 3 ). Drift to colonies with older virgin queens also increased relative to colonies with younger virgin queens in block 2 , with increases in age from $5-10$ to $20-25 \mathrm{~d},(P$ $<0.05$ ), but no significant interaction with drone age was evident in block 1 . In both blocks, drift to colonies with young virgin queens increased relative to queenless colonies with an increase in drone age from 5-10 to 20-25 d old (block 1, $P<$ 0.05 ; block $2, P<0.015$ ) (figs 2 and 3 ). In block 2 , drift to colonies with young virgin queens also increased relative to cagedmated queens with an increase in drone age from 5-10 to 20-25 d $(P<0.02)$ (fig 2). Although in block 1 , drift to colonies with caged-mated queens increased $(P<$ 0.02 ) relative to colonies that had virgin queens, with increased drone age (fig 3 ). 
The relative numbers of drones drifting to queenless colonies and colonies with mated queens also varied with drone age but only in colonies where queen state in the west position was altered (fig 3 ). In block 1 , drift to colonies with caged-mated queens increased relative to queenless colonies in 10-25-d-old drones $(P<0.02)$. Drift to queenright colonies was higher than to colonies with virgin queen when the drones were 10-20 d old but that trend was reversed in 5-10 and 20-25-d-old drones $(P<0.02)$ (fig 3 ).

\section{Retention of drones}

When queen state in the east position was altered (block 1), there were no significant differences in the relative number of drones retained by colonies and there was no interaction between colony queen state and drone age (fig 4). Queen state did affect the retention of drones when colony queen states were altered in the west position, $(P<0.004)$ (block 2); (fig 5). Drift from colonies with mated-laying queens was significantly lower $(P<0.025)$ than drift
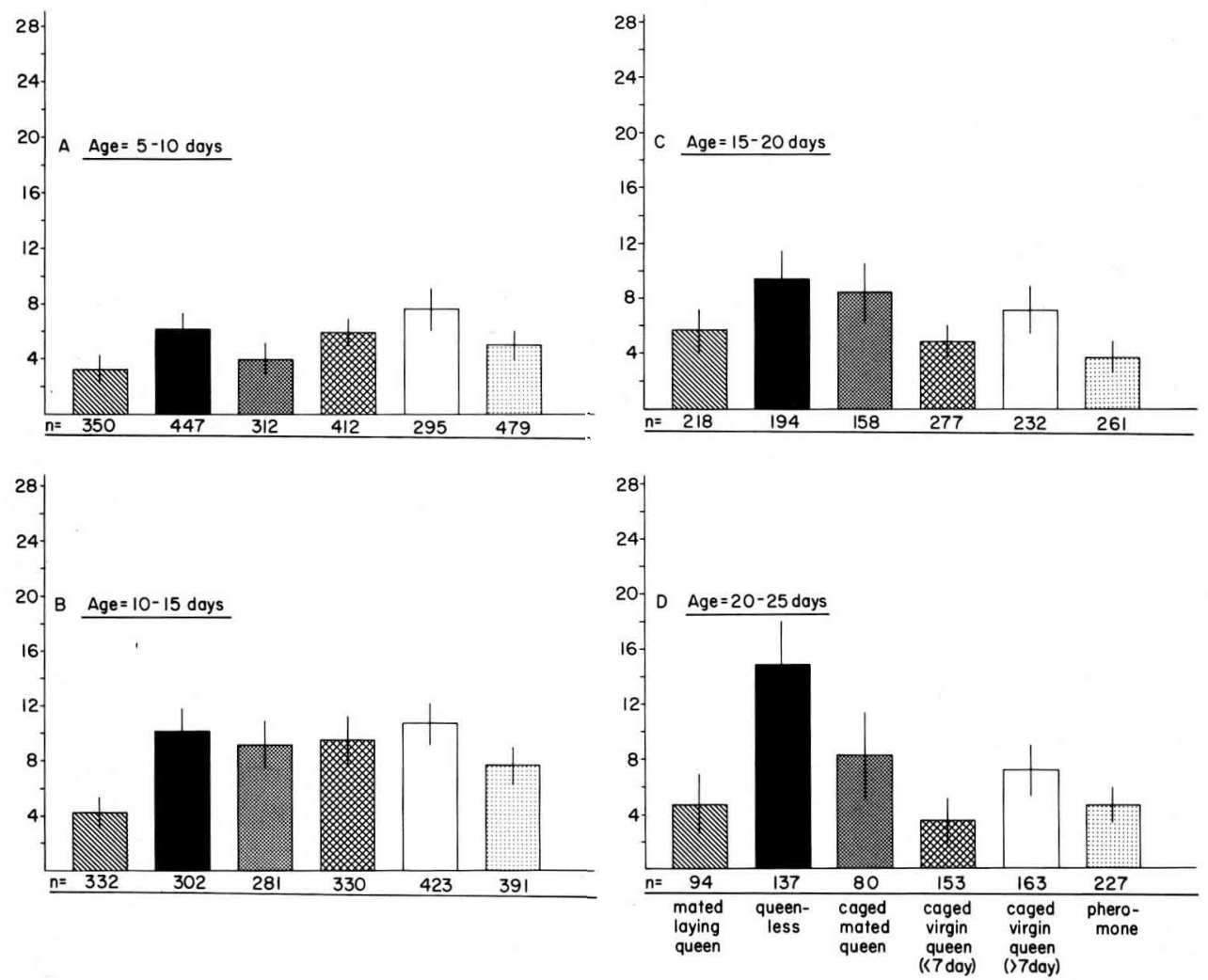

Fig 4. The retention of 4 age groups of drones by colonies with altered queen state, where drones drifted from treated colonies to queenright colonies $1 \mathrm{~m}$ to the east (block 1$) . n=$ total number of drones observed (on which proportions were based). 

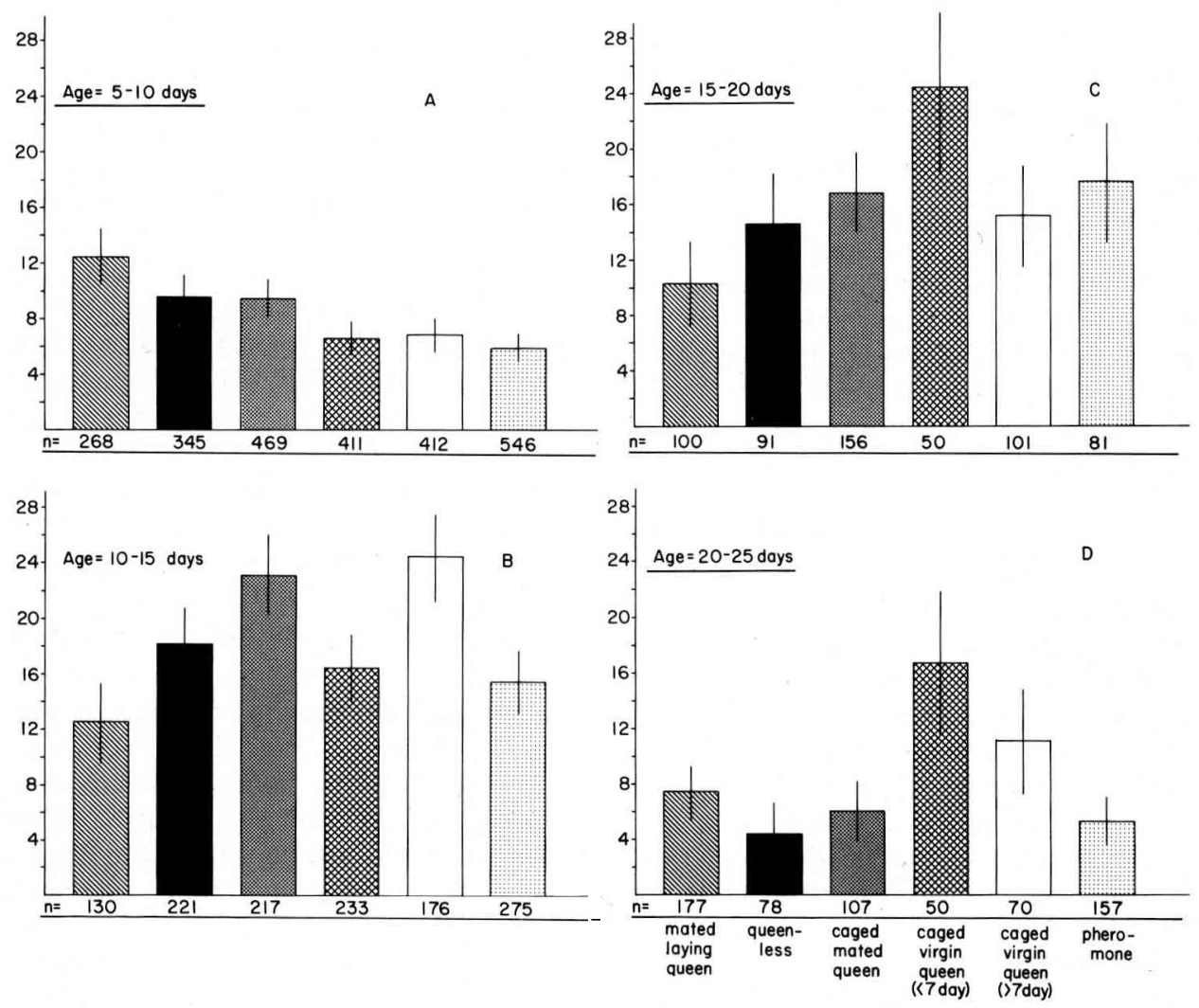

Fig 5. The retention of 4 age groups of drones by colonies with altered queen state, where drones drifted from treated colonies to queenright colonies $1 \mathrm{~m}$ to the west (block 2 ). $n=$ total number of drones observed (on which proportions were based).

rom colonies with caged-mated queens and drift from colonies treated with pheromone was significantly lower than drift from colonies with virgin queens $(P<$ 0.0006).

The relative number of drones that drifted from colonies with different queen states also varied with the age groups of the drones in block $1(P<0.001)$ (fig 5).
Drift away from colonies with virgin queens increased relative to drift from queenright colonies as the age of the drones increased $(P<0.04)$ from $5-15 \mathrm{~d}$ to $20-25$ d. Drift away from colonies with young virgin queens increased $(P<0.05)$ relative to colonies with caged-mated queens as the age of the drones increased from 15-20 d to $20-25 \mathrm{~d}$. 


\section{DISCUSSION}

In queenright hives, drone drift was greater towards the west than to the east (figs 2-5). The direction of drift did not appear to be correlated with wind direction, which varied greatly throughout the course of this study. In rows that face north or south, the drift of both workers and drones is higher towards the west than the east and appears to be influenced by the position or apparent movement of the sun across the sky during the day, irrespective of other environmental factors (Jay, 1966, 1968, 1971, 1984; Vollbehr, 1975; Currie and Jay, 1989). The directional bias found in this study was probably also caused by the tendency for drone drift to be influenced by the position and apparent movement of the sun (Currie, 1986; Currie and Jay, 1989). This resulted in a significant interaction between the direction of drone drift and numbers of drones drifting to hives with different queen states or pheromones. When the treated hives were placed on the west side of the south-facing pairs of hives, the differences between treatments appeared to be masked to some extent by high levels of drift to the queenright and queenless controls and differences between treatments were more variable (fig 4).

Differences in the rate of rejection of drones between queenless and queenright colonies, were not apparent in this study. In block 1, drift to queenright colonies and colonies with caged-mated queens was higher than to queenless colonies (fig 3). This was in contrast to the findings of Free and Spencer-Booth (1961), who found that more drones from queenright colonies drift to queenless colonies than to queenright colonies. Free and Spencer-Booth (1961) conducted their experiments in England from mid-August to September when guard bees at the hive entrance may have been more aggressive. In the current study, the rejection of drones by guard bees at the hive entrance was not observed.

Virgin queens (or their pheromones) might have influenced the behaviour of workers towards drones, thus making colonies with virgin queens (or pheromone) more tolerant of drifting drones than either queenless or queenright colonies. However, observations of colonies indicated that drones that had drifted during the day were not rejected by the workers before the next sampling period (Currie, 1986). Therefore, differences in drift between treatments could not have resulted from differences in the rejection of drones either by the colonies guard bees at the hive entrance, or by eviction of the drones between sampling periods.

Virgin queens produce a mating pheromone that attracts drones while in flight (Gary, 1962). More drones drifted to colonies that had virgin queens than to either queenless or queenright colonies (fig 2). The attraction of drifting drones appeared to result from the virgin queen's pheromones (fig 2). Drift to colonies containing (trans-9-ODA), in concentrations that were equal to or greater than those found in older virgin queens, confirmed that drones were attracted to colonies containing the major component of the queen's mandibular pheromone in lieu of a queen.

The proportion of drones that was attracted by the virgin queen's pheromone increased with the age of the drone (fig 2). Drones may not respond to the queen's pheromone until they are sexually mature (ie older). The period of increased attraction of drones to colonies with virgin queens coincided with the age when drones become sexually mature (9-23 d old) (Kurennoi, 1953; Jaycox, 1961; Ruttner, 1966; Woyke and Jasinski, 1978). It is not known if the age of the drone is impor- 
tant in their responsiveness to virgin queens on mating flights (Currie, 1986, 1987).

More of the older drones were attracted by virgin queens older than $7 \mathrm{~d}$ of age than by younger virgin queens (fig 2). This may have been caused by quantitative differences in the production of queen pheromone. The number of drones attracted to "lure-queens" (ie queens attached to poles or balloons) is proportional to the quantity of trans-9-ODA in the queen's mandibular glands (Boch et al, 1975). Very little 9ODA is found in newly emerged virgin queens and the quantity of pheromone increases to a maximum level when the virgin queen is from $5-10 \mathrm{~d}$ old (Pain et al, 1960; Butler and Paton, 1962).

Higher proportions of drones were attracted to colonies with 9-ODA than to those with either young or old virgin queens. The blocks containing pheromone were replaced daily so that similar concentrations of pheromone were administered over each day. However, the pheromone was mixed in batches and used over several days. Due to evaporation of the solvent the concentration of pheromone may have been higher than $100 \mu \mathrm{g}$, the level that would normally be found in an older virgin queen (Butler and Fairey, 1964).

In this study, colonies with mated queens (laying or caged) were not as attractive as colonies with virgin queens (fig 2). Mated queens produce the same quantity of 9-ODA as older virgin queens (Butler, 1961; Butler and Paton, 1962), and can attract as many or more drones to mating lures than virgin queens (Pain and Ruttner, 1963; Butler and Fairey, 1964; Boch et al, 1975). Differences in the attractiveness of mated and virgin queens to drifting drones may have been caused by qualitative differences in the queen's pheromone, perhaps with respect to relative contents of trans and cis isomers (Doolittle et al, 1970), or different enantiomers of $(e)$ 9-hydroxy-2-decenoic acid (Winston et al, 1982). Other qualitative differences in pheromone production between virgin and mated queens occur (Butler and Fairey, 1963, 1964; Slessor et al, 1990) and some odours and glands have been identified in virgin, but not mated, queens that may also function in the mating process (Renner and Baumann, 1964; Boch et al, 1975; Grandperrin and Cassier, 1983).

Drones from colonies that had either virgin queens or pheromone did not retain significantly more drones than either the queenright or queenless colonies (figs 4 and 5). This result agrees with the observations of Butler (1939) and Levenets (1951); but they also did not find that drones were attracted to colonies with virgin queens. Although drifting drones are attracted to neighbouring colonies with virgin queens, it appears that they are not attracted by virgin queens from their own colonies. When both members of a pair of colonies have the same queen state, the proportion of drones that drift between colonies with virgin queens does not vary significantly from queenless or queenright colonies (Currie and Jay, 1989). Drones from colonies that contain virgin queens may become habituated to the presence of the virgin queen's pheromones and thus are not attracted to other colonies with virgin queens (Currie, 1986, 1987).

The mechanism that prevents drones from pursuing and mating with queens from their own colony is not known. It was formerly believed that drones would not pursue queens at heights below $10 \mathrm{~m}$ (Ruttner, 1957; Butler and Fairey, 1964; Jacobson, 1972) or that drones would not pursue queens beyond congregation areas (Ruttner and Ruttner, 1963). However, several data seem to refute these hypotheses. Our data show that drones returning from flights were attracted to hives that 
had virgin queens (fig 2), drones have also been attracted to virgin queens at heights as low as 1-2 $\mathrm{m}$ (Gerig and Gerig, 1982; Tribe, 1982), and several authors have observed drones pursuing or mating with virgin queens returning to their hives from mating flights (Ruttner, 1966; Gary, 1971; Dixon, 1979).

It is possible that drones search for virgin queens only after a certain period of flight activity, and/or that drones are habituated to the virgin queen's pheromone from their own colony and thus cannot detect the virgin queens that leave on mating flights from their own colonies (Currie, $1986,1987)$. Thus, habituation to the virgin's pheromones might act as mechanism to prevent drones from mating with queens from their own colonies. More research is required to determine how the various components of virgin queen's pheromones influence mating behaviour of drones. Quantitative and qualitative differences in pheromone production between virgin and mated queens appeared to influence the drifting behaviour of drones. The relative attractiveness of these different states of queens to drones of different age groups should also be re-evaluated in flight. Research is also needed to determine how frequently drones mate with queens from their own colonies, and to determine if there is a physiological mechanism that acts to prevent inbreeding in honey bees.

\section{ACKNOWLEDGMENT}

We would like to thank $D$ Bielaszka who volunteered many hours to mark drones.

Résumé - Influence de l'état de la reine sur la dérive des mâles d'abeilles (Apis mellifera $L$ ). Des mâles ont été marqués individuellement avec des pastilles numérotées et introduits dans des ruches regroupées en 12 paires espacées d'1 m et situées face au sud. La colonie occidentale de chaque paire de ruches a conservé sa reine féconde pondeuse; l'autre colonie a été modifiée de la façon suivante : soit elle a reçu une reine encagée vierge âgée de moins de $7 j$, ou une reine encagée vierge âgée de plus de $7 \mathrm{j}$, ou une reine encagée féconde, ou une reine féconde et pondeuse, ou de l'acide céto- 9 trans décène-2 oïque (composé de la phéromone royale), soit elle a été orphelinée. Dans une autre série de paires, ce dispositif a été répété en modifiant cette fois-ci la colonie occidentale. L'expérience a été répétée 4 fois. On a étudié la dérive des mâles répartis en 4 classes d'âge $(5-10,10-15,15$ 20 et $20-25 \mathrm{j}$ ).

Les mâles ont dérivé en plus grand nombre vers les colonies qui possédaient une reine vierge encagée ou un leurre phéromonal que vers les colonies orphelines, les colonies avec reine féconde pondeuse ou celles qui avaient une reine féconde encagée. La proportion de mâles qui a dérivé vers les colonies renfermant une reine vierge a augmenté avec l'âge de ceux-ci. L'attraction des mâles vers les colonies avec reine vierge ou leurre phéromonal semble être en partie masquée dans le cas où les mâles ont dérivé vers des colonies modifiées placées à l'ouest, en raison d'une forte tendance à la dérive vers l'ouest dans les colonies témoins avec reine féconde pondeuse.

La dérive des mâles loin des colonies avec reine vierge n'est pas significativement plus faible que celle loin des colonies témoins ou des colonies orphelines. Les mâles semblent s'habituer à la phéromone des reines vierges de leur propre colonie. Cette habituation peut jouer un rôle dans la prévention de la consanguinité chez les abeilles. 
reine / phéromone / mâle / dérive / vol nuptial

\section{Zusammenfassung - Der Einfluß des Königin-Status eines Bienenvolkes auf} den Verflug der Drohnen. Drohnen wurden individuell mit Nummernplättchen markiert und paarweise aufgestellten Bienenvölkern (Abstand ein Meter) mit Flugrichtung Süd zugesetzt. Der KöniginStatus des östlichen Volkes jedes der 12 Völker-Paare wurde experimentell verändert (dh eine gekäfigte Jungkönigin unter 7 Tage alt, eine gekäfigte Jungkönigin über sieben Tage alt, eine begattete, legende Königin, das Volk war weisellos oder es erhielt eine Komponente der KöniginSubstanz Trans-9-Oxodezensäure. Das andere Volk des Paares blieb jeweils unverändert. Diese Versuchsanordnung wurde mit Völkerpaaren wiederholt, bei denen man den Königin-Status des westlichen Volkes in einem Paar veränderte. Der Versuch wurde vier Mal wiederholt. Der Verflug von vier Altersgruppen der Drohnen (5-10, 10-15, 15-20 und 20-25 Tage alt) wurde untersucht.

Resultate

Es verflog ein höherer Anteil Drohnen zu Völkern mit gekäfigten unbegatteten Königinnen oder zu Völkern, die mit einem Köder der Königin-Substanz (Trans-9Oxodezensäure) versehen waren, als zu weisellosen oder weiselrichtigen Völkern oder zu Völkern mit einer begatteten, gekäfigten Königin. Der Anteil von Drohen, der zu Völkern mit Jungköniginnen verflog, stieg mit dem Alter der Drohnen. Die Anlockung von Drohnen zu Völkern mit Jungköniginnen und zu solchen mit Ködern schien zu einem gewissen Maße maskiert zu werden, sobald Drohnen zu behandelten Völker in westlicher Position verflogen, da eine starke Tendenz des Verfluges in westlicher Richtung zu den weiselrichtigen Kontrollvölkern bestand.

Der Verflug von Drohnen aus Völkern heraus, die mit Jungköniginnen versehen waren, erwies sich als nicht signifikant geringer als der Verflug aus weiselrichtigen oder aus weisellosen Völkern. Bej den Drohnen scheint eine Gewöhnung (Habituation) an den Geruch (Pheromon) der Jungkönigin des eigenen Volkes einzutreten. Deshalb können sie die paarungsbereite Jungkönigin nicht entdecken, wenn sie das Volk für den Paarungsflug verläßt. Vermutlich beginnt die Suche der Drohnen nach Königinnen erst nach einer gewissen Dauer der Flugaktivität. Die Gewöhnung der Drohnen an die Pheromone unbegatteter Königinnen könnte bei der Vermeidung von Inzucht bei der Honigbiene eine Rolle spielen.

\section{Drohnen / Verfliegen / Königin / Phero- mone / Paarungsflug}

\section{REFERENCES}

Blum MS, Boch R, Doolittle RE, Tribble MT, Traynham JG (1971) Honeybee sex attractance: conformational analysis, structural specificity and lack of masking activity of congeners. J Insect Physiol 17, 349-364

Boch R, Shearer DA, Young YC (1975) Honeybee pheromones: field tests of natural and artificial queen substance. $J$ Chem Ecol 1, 133148

Butler CG (1939) The drifting of drones. Bee World 20, 140-142

Butler CG (1961) The scent of queen honeybees (Apis mellifera $L$ ) that causes partial inhibition of queen rearing. $J$ Insect Physiol 7, 258-264

Butler CG, Paton PN (1962) Inhibition of queen rearing by queen honeybees (Apis mellifera $L$ ) of different ages. Proc $R$ Entomol Soc Lond Ser A Gen Entomo/ 37, 114-116 
Butler CG, Fairey EM (1963) The role of the queen in preventing oogenesis in worker honey bees. J Apic Res 2, 14-18

Butler CG, Fairey EM (1964) Pheromones of the honeybee: biological studies of the mandibular gland secretion of the queen. $J$ Apic Res 3, 65-76

Currie RW (1982) Some factors affecting the orientation of drone honeybees. Univ Manitoba $\mathrm{MSc}$ thesis

Currie RW (1986) The effects of the position and apparent movement of the sun and a colony's queen state on the orientation of drone honey bees (Apis mellifera $\mathrm{L}$ ) to their hives. Univ Manitoba, $\mathrm{Ph} D$ Thesis

Currie RW (1987) The biology and behaviour of drones. Bee World 68, 129-143

Currie RW, Jay SC (1988) Factors affecting the acceptance of foreign drones into honey bee (Apis mellifera L) colonies. Apidologie 19, 231-240

Currie RW, Jay SC (1989) Sun position and a colony's queen state as possible factors influencing the orientation and drift of drone honeybees (Apis mellifera L). J Apic Res 28, $142-149$

Dixon DP (1979) Factors affecting the production of honeybee queens (Apis mellifera $L$ ). Univ Manitoba, MSc thesis

Doolittle RE, Blum MS, Boch R (1970) Cis-9oxo-decenoic acid: synthetic and evaluation as a honeybee pheromone and masking agent. Ann Entomol Soc Am 63, 1180-1185

Free JB, Spencer-Booth $Y$ (1961) Further experiments on the drifting of honey-bees. $J$ Agric Sci 57, 153

Gary NE (1962) Chemical mating attractants in the honeybee. Science 136, 773-774

Gary NE (1971) Observations on flightexperienced queen honeybees following extra-apiary release. $J$ Apic Res 10, 3-9

Gerig L, Gerig A (1982) Einfangen von Bienen und Drohnen (Apis mellifera $L$ ) mit modellflugqueggeschlepptem Fangsack. Schweiz Bienen-Ztg 99, 379-391

Grandperrin D, Cassier P (1983) Anatomy and ultrastructure of the Koschewnikow's gland of the honeybee, Apis mellifera $L$ (Hymenoptera: Apidae). Int $J$ Insect Morphol Embryol $12,25-42$
Jacobson M (1972) Insect Sex Pheromones. Academic Press, N Y, 382 pp

Jay SC (1966) Drifting of honeybees in commercial apiaries. I. Effect of various environmental factors. J Apic Res 5, 167-175

Jay SC (1968) Drifting of honeybees in commercial apiaries. IV. Further studies of the effect of apiary layout. J Apic Res 7, 37-44

Jay SC (1971) Sun position as a possible factor in the disorientation of honeybees (Apis mellifera) (Hymenoptera: Apidae). Can Entomol 103, 1111-1114

Jay SC (1984) Sun position as a possible factor in the disorientation of honeybees in the southern hemisphere. J Apic Res 23, 143147

Jaycox ER (1961) The effects of various foods and temperatures on sexual maturity of the drone honeybee (Apis mellifera). Ann Entomol Soc Am 54, 519-523

Kurennoi NM (1953) Flight activity and sexual maturity of drones. Pchelovdstvo 31, 24-28 (in Russian)

Laidlaw HH, Eckert JE (1974) Queen Rearing. Univ California Press, Los Angeles, CA

Levenets IP (1951) The drifting of drones. Pchelovodstvo 29, 25-30 (in Russian)

Pain J (1973) Pheromones and hymenoptera. Bee World 54, 11-24

Pain J, Ruttner F (1963) Les extracts des glandes mandibulaires des reines d'abeilles attirent les mâles, lors du vol nuptial. $C R$ Hebd Seanc Acad Sci Paris 256(D), 512-515

Pain J, Hugel MF, Barbier M (1960) Sur les constituants du mélange attractif des glandes mandibulaires des reines d'abeilles (Apis mellifera $L$ ) à différents stades de leur vie. $C$ $R$ Hebd Seanc Acad Sci Paris 283(D), 797799

Renner M, Baumann M (1964) Über komplexe von subepidermalen Crusenzellen (Duftrusen?) der Bienenkonigin. Naturwissenschaften 51, 68-69

Ruttner $F$ (1957) Die Sexualfunktionen der Honigbienen im Dienste ihren sozialen Gemeinschaft. $Z$ Vgl Physiol 39, 577

Ruttner F, Ruttner H (1963) The flight activity and mating behaviour of drones. Bienenvater $84,297-301$ (in German) 
Ruttner $F$ (1966) The life and flight activity of drones. Bee World 47, 93-100

Slessor KN, Kaminski L, King GGS, Winston ML (1990) Semiochemicals of the honeybee queen mandibular glands. $J$ Chem Ecol 16, 851-860

Snedecor GW, Cochran WG (1980) Statistical Methods. The lowa State University Press, Ames, IA, $507 \mathrm{pp}$

Tribe GD (1982) Drone mating assemblies. $S$ Afr Bee J 54, 99-100; 103-112
Vollbehr Von J (1975) Zur Orientierung junger Honigbienen bei ihrem 1. Orientierungsflug. Zool Jahrb Abteil Allg Zool Physiol Tiere 79, 33-69

Winston ML, Slessor KN, Smirle MJ, Kandil AA (1982) The influence of a queen-produced substance, 9-HDA, on swarm clustering behaviour in the honeybee Apis mellifera L. $J$ Chem Ecol 8, 1283-1288

Woyke J, Jasinski $Z$ (1978) Influence of age of drones on the results of instrumental insemination of honeybee queens. Apidologie 9, 203-211 